\title{
Pelatihan Penerapan Social Media Marketing sebagai Media Promosi Agrowisata di Desa Bunga Raya Kecamatan Bunga Raya, Kabupaten Siak
}

\author{
Evawani Elysa Lubis, Belli Nasution, Anuar Rasyid, Nova Yohana \\ Jurusan IImu Komunikasi, Fakultas IImu Sosial dan Ilmu Politik, Universitas Riau \\ evawani.elysa.lubis@lecturer.unri.ac.id, nova.yo7@gmail.com, anuar.rasyid@lecturer.unri.ac.id
}

\begin{abstract}
Abstrak
Pemerintah Daerah Kabupaten Siak telah mencanangkan pengembangan potensi agrowisata Kampung Bunga Raya, Kecamatan Bunga Raya sejak tahun 2017. Berbagai persiapan telah dilakukan agar program tersebut dapat terlaksana dengan baik. Berdasarkan analisis situasi keberadaan agrowisata di daerah tersebut masih relatif baru dan belum diketahui oleh masyarakat luas. Dalam hal ini dibutuhkan sumberdaya manusia yang handal dalam melakukan kegiatan promosi mengenai potensi agrowisata tersebut. Kegiatan pengabdian ini bertujuan untuk memberikan pelatihan dan pendampingan pemanfaatan social media marketing sebagai media promosi agrowisata di Bungaraya oleh khalayak sasaran seperti masyarakat yang memiliki usaha agrowisata dan tergabung dalam pokdarwis. Metode yang digunakan adalah penyuluhan mengenai perkembangan teknologi komunikasi serta pendampingan pemanfaatan media sosial sebagai media promosi, praktek penggunaan media sosial berupa facebook dan instagram, membuat akun, membuat hastag, mengupload gambar yang menarik tentang agrowisata, mengundang teman dan menyusun narasi yang menarik. Hasil dari kegiatan ini adalah para peserta yang memiliki usaha agrowisata mengetahui dan memahami tentang social media marketing dan memiliki bekal cara yang kerja yang lebih baik dalam mempromosikan agrowisata untuk meningkatkan kunjungan wisatawan ke Kampung Bunga Raya.
\end{abstract}

Kata kunci: pelatihan, pendampingan, social media marketing, agrowisata, pokdarwis.

\section{Pendahuluan}

Pengembangan agrowisata merupakan upaya terhadap pemanfaatan potensi atraksi wisata pertanian. Berdasarkan Surat Keputusan (SK) bersama Menteri Pariwisata, Pos, dan Telekomunikasi (Menparpostel) dan Menteri Pertanian No. KM/PW.DOW/MPPT 89 dan No. 204/KPTS/HK/050/4/1989, agrowisata sebagai bagian dari objek wisata diartikan sebagai suatu bentuk kegiatan yang memanfaatkan usaha agro sebagai obyek wisata dengan tujuan untuk memperluas pengentahuan, pengalaman rekreasi,dan hubungan usaha di bidang pertanian

Agrowisata merupakan bagian dari objek wisata yang memanfaatkan usaha pertanian (agro) sebagai objek wisata. Tujuannya adalah untuk memperluas pengetahuan, pengalaman, rekreasi, dan hubungan usaha d bidang pertanian. Mellaui pengembangan agrowisata yang menonjolkan budaya lokal dalam memanfaatkan lahan dapat meningkatkan pendapatan petani sambil melestarikan sumber daya lahan serta memelihara budaya maupunteknolodi lokal (indigenous knowledge) yang umumnya telah sesuai dengan kondisi lingkungan alaminya.

Salah satu wilayah yang ada di Provinsi Riau yang saat ini tengah mengembangkan potensi agrowisata di daerahnya adalah Kampung Bunga Raya yang terletak di Kecamatan Bunga Raya, Kabupaten Siak. Di Kampung Bunga Raya secara umum berada pada posisi dataran 


\section{Jcommdev}

JCommdev- JOURNAL OF COMMUNITY DEVELOPMENT \& EMPOWERMENT

dan mayoritas penduduknya bekerja di sektor pertanian tanaman padi dan palawija serta berbagai jenis holtikultura, sehingga Kecamatan ini dijuluki sebagai sentral lumbung pangan di Kabupaten Siak.

Wilayah Kecamatan Bunga Raya pada umumnya tidak jauh berbeda dengan wilayah kecamatan lainnya di Kabupaten Siak yang merupakan dataran rendah, bergelombang dan sedikit berbukit dengan struktur tanah yang pada umumnya terdiri dari tanah padsolid merah kuning dari batuan dan alluvial, tanah gambut, tanah orgosol dan gleyhumus dalam bentuk rawa-rawa atau tanah basah. Kecamatan Bunga Raya memiliki jumlah penduduk 24.222 orang dengan 6.455 Kepala Keluarga (KK) dari 31 dusun, 60 Rukun Kampung (RK) dan 152 Rukun Tetangga (RT) dari 10 desa di Kecamatan Bunga Raya yakni: Kampung Bunga Raya, Kampung Jaya Pura, Kampung Tuah Indrapura, Kampung Buantan Lestari, Kampung Kemuning Muda, Kampung Jati Baru, Kampung Dayang Suri, Kampung Temusai, Kampung Langsat Permai dan Kampung Suak Merambai. (Kabupaten Siak Dalam Angka, 2019)

Sejak tahun 2017 pemerintah Kabupaten Siak telah mencanangkan Kecamatan Bunga Raya sebagai daerah agrowisata. Grand design agrowisata Kecamatan Bunga Raya telah dirancang oleh tim agrowisata diantaranya melalui agenda atau event-event agrowisata yang mengkolaborasikan potensi indahnya hamparan persawahan yang luas dan indah dengan wisata seni dan budaya,wisata edukasi pertanian, wisata kuliner, dan lainnya. Persiapan lain yang telah dilakukan dalam mewujudkan rancangan tersebut adalah pembangunan fisik seperti pembangunan pintu gerbang, area parkir, saung agrowisata, sarana hiburan dan permainan, dan marka agrowisata. Pemerintah setempat juga akan berkonsultasi dengan MUI terkait usulan rancangan pembangunan tugu panglima dan tugu tani di Kecamatan Bunga Raya.

Pada saat ini ada empat destinasi agrowisata yang dapat dikunjungi oleh wisatawan di Kabupaten Siak, khususnya Kecamatan Bunga Raya, seperti Taman Bunga Menara Lestari yang dibangun oleh Kelompok Sadar Wisata (Pokdarwis) Nuansa Lestari yang berada di Kampung Buantan Lestari, Taman Harmoni Raya dan Taman Mina Padi Sakabura yang digiatkan oleh Pokdarwis Alam Raya Bertuah di Kampung Bungaraya serta ekowisata Taman Berembang yang dikelola oleh Pokdarwis Alam Berembang Bertuah di Kampung Suak Merambai. Destinasi agrowisata yang ada di Kecamatan Bungaraya tersebut adalah merupakan swadaya masyarakat dan selanjutnya dibina oleh Dinas Pariwisata Kabupaten Siak.

Selanjutnya, dalam rangka menyebarluaskan informasi keberadaan lokasi agrowisata di Kampung Bunga Raya tersebut perlu adanya aktivitas promosi melalui berbagai saluran komunikasi. Saat ini, media komunikasi pemasaran melalui media online merupakan pilihan utama yang dapat diambil mengingat tingginya penggunaan masyarakat luas terhadap media tersebut. Media online dapat digunakan sebagai sarana pemasaran untuk menarik minat masyarakat berkunjung ke agrowisata yang terletak di Bunga Raya. Informasi terkait agrowisaa yang ada di Bungaraya tersebut banyak disebarluaskan oleh media-media online seperti goriau.com, gonews.co, publiknews.com, dan halloriau.com. informasi tentang agrowisata di Siak tersebut banyak dimuat pada media berita online yang isinya bersifat umum dan kadang kala berupa pengulangan informasi dari situs berita yang lain.

Keberadaan internet memunculkan paradigma baru mengenai pemasaran, berupa pemasaran modern berorientasi pasar/konsumen atau revolusi pemasaran berupa electronic JCommdev Vol 1, No. 2, 2020, hlm. 103 - 112 


\section{Jcommdev}

JCOmmdev- JOURNAL OF COMMUNITY DEVELOPMENT \& EMPOWERMENT

marketplace (Amoott dan Bridgewater, 2002:86; Bakos,1999:1613; Chaffey et.al, 200; Eid dan Trueman, 2002:54 dalam Sutejo, 2006:2). Internet marketing atau yang sering disebut pemasaran online melalui penggunaan teknologi internet (Jones, malczyk,et.al, 2010:4). Perkembangan internet marketing juga mendorong penggunaan media sosial dalam komuniksi pemasaran, atau bisa disebut dengan social media marketing. Jenis media sosial yang terdapat dalam internet marketing yang digunakan sebagai alternatif untuk proses pemasaran dan melakukan interaksi dengan konsumen menurut Micheal A Stelzner terdiri dari Youtube, Facebook, Twitter, Blogs, Linkdln, Google+, Pinterest, Photo Sharing Sites, Forum, Podcast, Social Boomarking, Geo Location, Q\&A Sites, dan Daily deal (Stelzner, 2013: 29-36).

Social media marketing adalah proses dimana individu dan perusahaan melakukan kegiatan promosi tentang website, produk ataupun jasa yang dihasilkan serta pelayanan secara daring melalui media sosial kepada komunitas yang jauh lebih besar dibandingkan dekang media periklanan secara tradisional. (Drury, 2008:274 dalam Rizal dan Lubis, 2014:105)

\section{Metode Pelaksanaan}

Kegiatan pengabdian kepada masyarakat ini dilakukan selama tiga (3) bulan yang terdiri dari beberapa tahapan yaitu:

\section{a. Tahap Persiapan}

Tahap persiapan ini merupakan tahap awal yang diperlukan untuk mengumpulkan data ataupun informasi yang terkait dengan kelompok sasaran dari kegiatan pengabdian ini. Tahap persiapan ini terdiri dari bebrapa kegiatan, yaitu:

1) Mengadakan pertemuan dengan anggota tim pelatihan untuk mendiskusikan materi kegiatan yang akan diaksanakan dan pembagian tugas antar tim pelaksana kegiatan pengabdian masyarakat ini.

2) Melakukan koordinasi dengan mahasiswa Universitas Riau yang melaksanakan Kuliah Kerja Nyata di Kampung Bungaraya terkait dengan pelaksanaan kegiatan pengabdian tersebut.

3) Mengadakan pertemuan dengan Camat dan Kepala Kampung Bungaraya serta tim agrowisatanya guna mendapatkan izin pelaksanaan dan penetapan jadwal kegiatan.

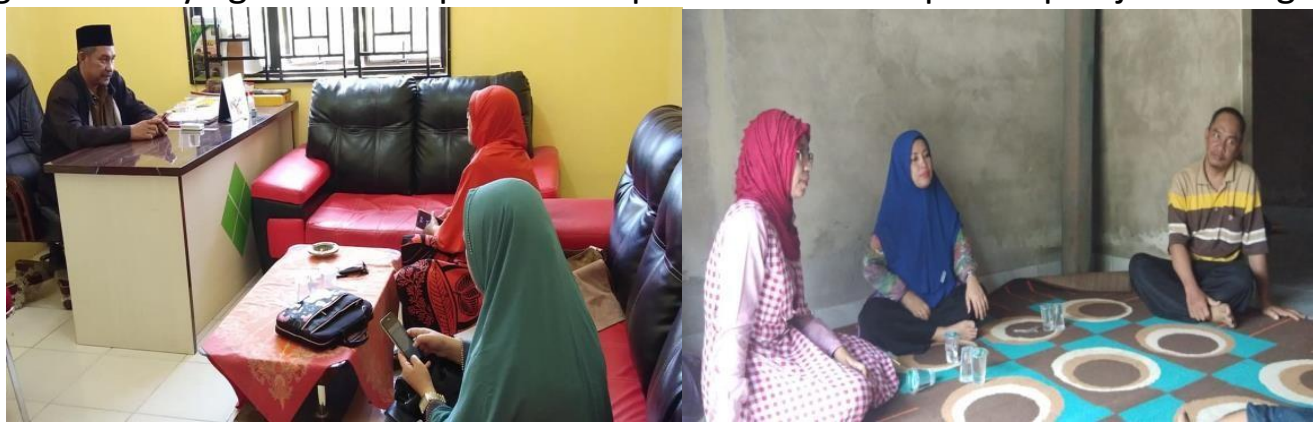

Gambar 1. Koordinasi dengan pihak Kecamatan dan Kepala Kampung Bungaraya Sumber: Dokumentasi tim pengabdian, 2019 


\section{int

4) Mengumpulkan data calon peserta pelatihan yang terdiri dari anggota Pokdarwis, pelaku usaha pendukung agrowisata, pemerintah dan masyarakat umum yang peduli dengan pengembangan destinasi agrowisata di daerah Bungaraya tersebut.

5) Mengidentifikasi potensi lain dari daerah Bungaraya tersebut yang dapat dimanfaatkan untuk mendukung pengembangan agrowisata, misalnya adat istiadat, seni tradisional, produk-produk khas yang dapat dijual sebagai buah tangan yang ada di daerah Bungaraya.

6) Mempersiapkan materi untuk pelatihan dan pendampingan, peralatan maupun bahan yang diperlukan dalam kegitan pengabdian kepada masyarakat tersebut.

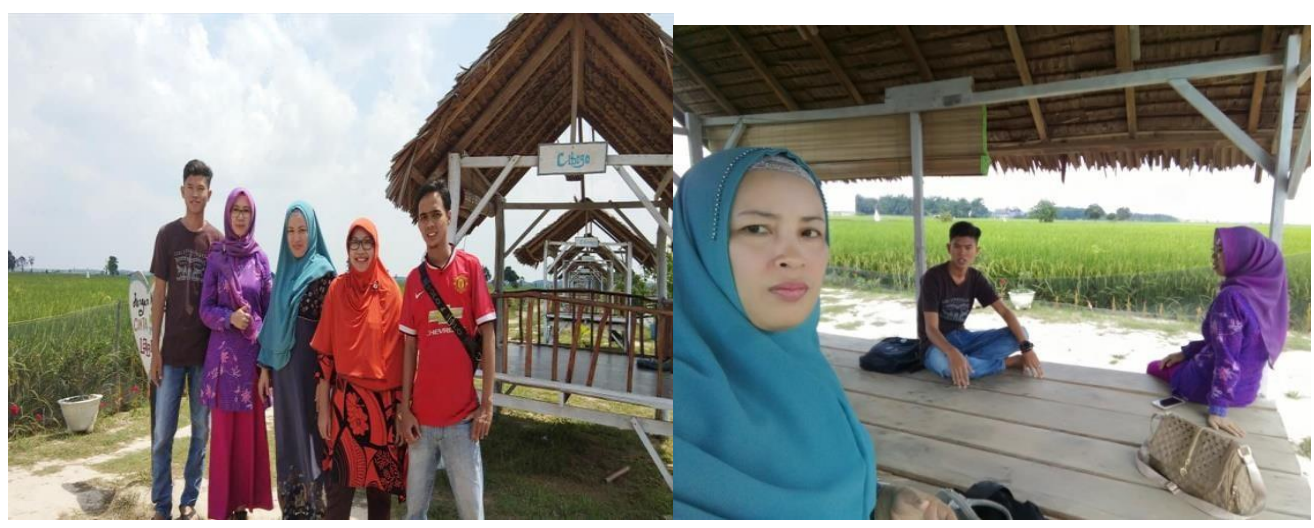

Gambar 2. Koordinasi dengan Pokdarwis di objek agrowisata Harmoni Raya Sumber: Dokumentasi tim pengabdian, 2019

\section{b. Tahap Pelaksanan Kegiatan}

Pada tahap ini pelaksanaan kegiatan pengabdian kepada masyarakat ini berupa pelatihan dan pendampingan dalam pemanfaatan social media marketing. Pada pelaksanaannya kegiatan ini berupa penyuluhan, bimbingan, diskusi serta tanya jawab antara tim pengabdian dengan para peserta yang menjadi sasaran kegiatan. Pada tahap ini dibutuhkan komunikasi yang intensif secara tatap muka dan berkelanjutan agar tujuan dari kegiatan ini dapat dicapai.

1) Acara Pembukaan yang diselenggarakan oleh tim pengabdian dengan kata sambutan dari ketua tim pengabdian dan pihak Kecamatan Bungaraya serta pembacaan doa.

2) Acara inti dari kegiatan pengabdian dengan judul 'Pelatihan Dan Pendampingan Penerapan Social Media Marketing Sebagai Media Promosi Agrowisata Di Desa Bunga Raya Kecamatan Bunga Raya Kabupaten Siak', dengan rangkaian acara sebagai berikut:

a. Pemaparan materi tentang sosial media marketing yang dapat dijadikan media promosi bagi penggiat agrowisata, hal ini diberikan untuk memberikan wawasan 


\section{ien

bahwa media sosial dapat dijadikan sebagai saluran promosi objek wisata dan juga untuk mengembangkan brand destination.

b. Pelatihan pembuatan akun media sosial facebook dan instagram oleh para peserta. Pada awal pembuatan sosial media marketing tersebut sangatlah penting untuk menentukan tujuan pembuatannya yang spesifik dan juga terukur. Tujuannya dapat berupa membentuk brand awareness ataupun meningkatkannya. Untuk sebuah daerah tujuan wisata, brand daerah tersebut disebut brand destination.

c. Sebelum materi disampaikan tim pengabdian telah mengidentifikasi peserta yang hadir serta apa saja yang telah mereka usahakan dalam mendukung pengembangan destinasi agrowisata di Bungaraya. Peserta yang hadir ada yang dari Pokdarwis, pihak kecamatan serta masyarakat yang memiliki lahan pertanian seperti sawah serta taman bunga, masyarakat yang menjual makanan ataupun usaha home stay.

d. Pada saat materi pelatihan disampaikan pembicara juga mengidentifikasi para peserta yang memiliki media sosial dan yang sudah mencoba untuk melakukan promosi usahanya terkait agrowisata di media sosialnya.

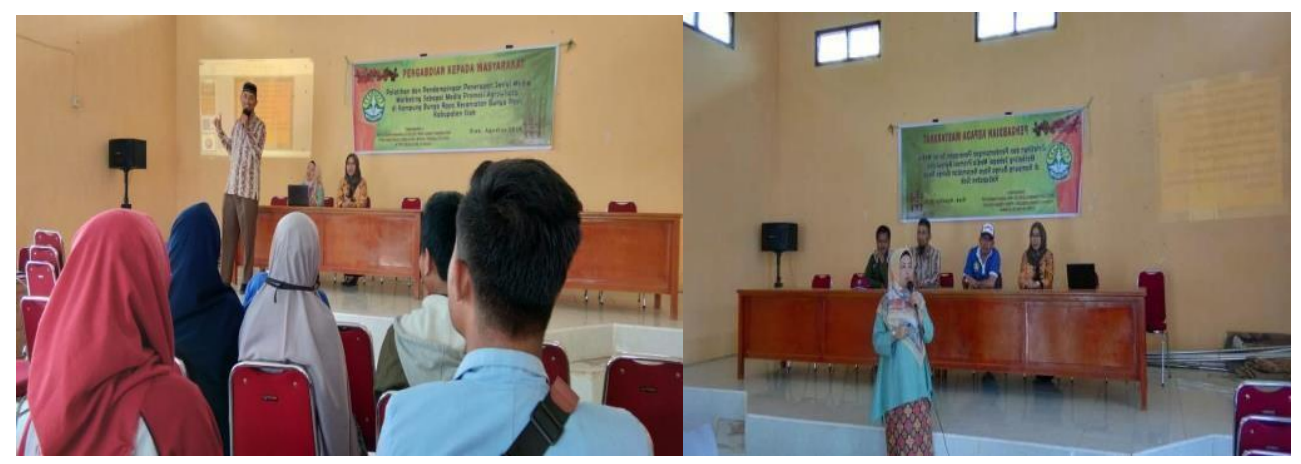

Gambar 3 Pelaksanaan kegiatan pelatihan dan pendampingan Sumber : Dokumentasi tim pengabdian, 2019

\section{Hasil dan Pembahasan}

Pada kegiatan pengabdian kepada masyarakat ini ada dua kelompok masyarakat yang menjadi sasarannya yaitu para penggiat kelompok sadar wisata (Pokdarwis) yang ada di sekitar Kecamatan Bungaraya, Kabupaten Siak serta masyarakat umum yang memiliki usaha terkait dengan agrowisata. Wilayah Kecamatan Bungaraya ini beratasan di sebelah Utara adalah Kecamatan Sabuk Auh dan Kecamatan Siak Kecil, Kabupaten Bengkalis. Di sebelah Selatan kecamatan ini berbatasan dengan Sungai Siak dan Kecamatan Siak. Sementara itu di sebelah Barat berbatasan denan Kecamatan Sungai Mandau dan Kabupaten Bengkalis. Di sebelah Timur berbatasan dengan Sungai Siak dan Kecamatan Sabak Auh. Luas wilayah Kecamatan Bungaraya 


\section{Jcommdev}

JCOmmdev- JOURNAL OF COMMUNITY DEVELOPMENT \& EMPOWERMENT

ini adalah 161,34 $\mathrm{Km}^{2}$, dan terletak pada $0^{\circ} 39^{\prime}-1^{\circ} 04^{\prime} \mathrm{LU}$ dan $101^{\circ} 58^{\prime}-102^{\circ} 13^{\prime} \mathrm{BT}$. Pada kecamatan Bungaraya ini juga terdapat beberapa sungai yaitu: sungai Cabang Kembangbunga, sungai Kembangbunga, sungai Raya, Sungai Tembutun, sungai Tasip. Sementara itu keadaan alam dari Kecamatan Bngaraya ini, hutan yang dulu cukup luas saat ini telah beralih fungsi menjadi lahan pertanian, perkebunan serta pemukiman. Tanaman yang banyak ditanam pada kecamatan ini adalah padi, palawija serta tanaman holtikultura. Oleh karena itu kecamatan Bungaraya saat ini telah menajdi sentral lumbung padi di wilayah Kabupaten Siak.

Jumlah penduduk Kecamatan Bungaraya pada tahun 2018 adalah 26.898 jiwa dengan laju pertumbuhan penduduk tertinggi setiap tahunnya di Kabupaten Siak sebesar 3,08 persen. Sebagian besar penduduknya bertani dan berkebun serta berdagang dan pegawai. Lahan pertanian yang diusahakan berupa lahan sawah, holtikulturan dan perkebunan.

\section{Potensi Agrowisata di Kecamatan Bungaraya}

Berdasarkan data monografi dan demografi yang telah dipaparkan maka Kabupaten Siak, khususnya Kecamatan Bungaraya sangatlah ideal menjadi tempat pengembangan agrowisatayang cukup berkembang di masa datang. Ada empat destinasi agrowisata yang dapat dikunjungi wisatawan bila berada di Kecamatan Bungaraya seperti: Taman Bunga Lesatri, Taman Harmoni Raya, Taman Mina Padi Sakabura, ekowisata Taman Berembang. Potensi agrowisata ini berupa tanaman padi dan holtikultura yang diusahakan dengan swadaya masyarakat bersama kelompok sadar wisata (pokdarwis):

a. Taman Harmoni Raya dan Taman Mina Padi Sakabura, merupakan lahan persawahan yang cukup luas dan sangat cantik dengan hamparan tanaman padi yang menghijau. Pada areal sawah ini telah dibangun spot foto agar pengunjung dapat berswa foto sambil menikmati keindahan pemandangan persawahan yang menyejukkan mata. Taman Mina Padi Sakabura di kelola oleh pokdarwis Alam raya Bertuah

b. Taman Bunga Menara Lestari, yaitu agrowisata yang berisi taman bunga dan areal persawahan yang asri. Di taman ini terdapat menara yang bernama Menara Lestari, pengunjung dapat menikmati pemandangan yang indah dari menari ini. taman ini dikelola oleh pokdarwis Nuansa Lestari.

c. Ekowisata Taman Berembang Pokdarwis Alam Berembang Bertuah di Kampung Suak Merambai. Taman ini menonjolkan ekowisata tanaman mangrove, yang dapat menajdi alternatif bagi pengunjung yang datang ke Bungaraya.

d. Selain destinasi agrowisata, pemerintah Kecamatan Bungaraya telah merancang event yang cukup menarik yaitu Tour de Sawah (TDS), merupakan kegiatan bersepeda yang dilaksanakan di areal persawahan. Tour de Sawah ini dimulai dari halaman Kantor Camat Bungaraya dan finish di Taman Harmoni Raya. Event TDS ini telah masuk dalam kalender pariwisata Siak dan bekerja sama dengan Teras Riau dan Yayasan Belantara dalam pembuatan grand desing agrowisata di setiap desa pada Kecamatan Bungaraya. Selain itu terdapat event yang menarik seperti main bola kaki di sawah, bola volley di sawah dan balapan traktor yang diharapkan dapat menarik wisatawan untuk datang.

e. Dari hasil observasi lapangan diketahui bahwa masyarakat Kecamatan Bungaraya sebagaian besar telah memiliki kesadara wisata yang cukup tinggi. Hal ini terbukti dari 
swadaya masyarakat dalam mengembangkan potensi agrowisata. Pokdarwis yang terbentuk banyak diinisiasi oleh para pemuda daerah dengan pengembangan ide yang cukup kreatif.

f. Potensi agrowisata yang sangat besar di Kecamatan Bungaraya tersebut ternyata masih mengahadapi kendala terkait dengan kunjungan wisatawan yang datang mengunjungi agrowisata tersebut. Masih kurangnya promosi yang dilakukan oleh pengelola taman agrowisata yang ada di kecamatan ini.

\section{Pemanfaatan Social Media Marketing sebagai Media Promosi Agrowisata Siak}

Pada awal kegiatan pelatihan ini, tim pengabdian telah dapat mengidentifikasi bahwa sebagian besar peserta belum mengetahui tentang manfaat media sosial sebagai media komunikasi pemasaran yang cukup popular pada saat ini. Selain itu yang paling mendasar dari kegiatan ini diketahui bahwa ada sebagain besar para peserta penyuluhan belum mengetahui tentang promosi destinasi agrowisata yang telah dibukanya. Informasi terkait agrowisata di Kecamatan Bungaraya ini hanya terdapat di situs berita online dan situs resmi pemerintah Kabupaten Siak yang ditampilkan dalam beritanya. Belum ada pemanfaatan media sosial yang dibuat sendiri oleh penggiat agrowisata tersebut yang dikelola secara optimal. Mereka hanya mengusahakan mempercantik destinasi agrowisatanya sehingga sangat menarik jika di foto oleh pengunjung. Ada beberapa pengunjung yang telah memposting fotonya dengan latar agrowisata Bungaraya namun hal ini tidak menjadi bagian dari usaha promosi yang dilakukan oleh penggiat agrowisata yang dalam hal ini adalah Pokdarwis. Walaupun demikian para peserta sangat menyambut baik akan kegiatan pelatihan dan pendampingan ini. Dari pendekatan dan komunikasi secara informal dengan para perserta pelatihan tim mendapatkan informasi bahwa para peserta telah mengenal media sosial seperti facebook dan instagram. namun pemanfaatan media sosial tersebut sebagai media promosi bagi usahanya khususnya agrowisata masihlah sangat kurang. Namun dari hasil pengamatan tim penyuluhan diketahui bahwa sebagian besar peserta telah memiliki cellphone yang dapat terhubung dengan internet.

Materi penyuluhan yang diberikan dalam kegiatan ini memberikan wawasan dan pengetahuan yang baru bagi para penggiat agrowisata tersebut dan para pengusaha yang terkait dengan agrowisata di Kecamatan Bungaraya. Pada pelaksanaan awal dari penyuluhan ini tim mencoba untuk mengetahui sejauh mana pengetahuan peserta tentang media sosial yang sangat berkembang pesat pada saat ini. Dari dialog yang dilakukan diketahui bahwa para peserta memang mengetahui tentang media social dan juga sudah memiliki teknologi komunikasi untuk dapat mengakses internet dan media social tersebut. Diketahui pula bahwa sebagian besar peserta juga sudah mulai mengakses media social tersebut seperti facebook. Namun dalam pemanfaatan media social sebagai media promosi dalam komunikasi pemasaran bagi usaha agrowisata belum menjadi media alternative dalam kegiatan promosinya. Dari kegiatan pelatihan dan penyuluhan ini juga terlihat bahwa para peserta sangat antusias untuk mengetahui cara pemanfaatan media social tersebut. Hal ini disebabkan bahwa pemanfaatan media social untuk media promosi snagatlah mudah, dan tidak memerlukan biaya yang besar.

Pada pelatihan ini dijelaskan bahwa pemanfaatan media sosial sebagai media promosi maka media sosial tersebut harus dikelola dengan baik. Pengelolaan media sosial tersebut harus bedasarkan strategi yang tepat dengan menentukan:

JCommdev Vol 1, No. 2, 2020, hlm. 103 - 112 
1) Mengelola media sosial tanpa strategi sama saja bekerja tanpa rencana. Tidak jelas target apa yang ingin dicapai, siapa yang ingin dijangkau, dan masalah apa yang ingin diselesaikan.

2) Menjalankan social media marketing tanpa strategi akan berakibat negatif terhadap bisnis yang dijalankan. Oleh karena itu, langkah pertama social media marketing adalah menyusun strategi. Ada beberapa strategi yang dapat diterapkan, seperti:

a. Riset Audiens, untk mengetahui karakteristik audiens dan platform media sosial yang tepat untuk digunakan.

b. Buat Goals yang jelas, menentukan tujuan sosial media marketing sebelum kampanye. Tujuan tersebut haruslah spesifik dan terukur. Salah satu tujuan social media marketing untuk meningkatkan brand awaraness. Untuk daerah wisata disebut juga dengan barnd destination.

c. Gunakan matriks yang benar; untuk mengetahui apakah tujua telah tercapai.

d. Riset kompetitor; pelajari media sosial kompetitor seperti keyword, hastag, hingga konsep konten yang diterapkan.

e. Buat konten yang rekevan dan menarik

f. Tentukan waktu posting yang tepat

g. Memanfaatkan advertise di platform media sosial yang digunakan.

h. Evaluasi performa media sosial yang digunakan.

Sebelumnya para anggota pokdarwis yang membuka usaha agrowisata ini belumlah begitu tertarik untuk merancang program komunikasi premasaran ataupun promosi dalam pemasaran mereka. Kegiatan promosi yang dilakukan sebatas spanduk, pemberitaan dari media online, bagian promosi dari situs resmi Pemerintah Kabupaten Siak serta informasi dari mulut ke mulut (WOM/Word of Mouth)), yang dirasakan kurang dapat menjangkau khalayak atau target sasaran yang luas. Sementara itu pemanfaatan media konvensional juga cukup membutuhkan dana yang besar. Oleh sebab itu media promosi melalui media social ini dapat menjadi media alternatif yang memberikan keuntungan bagi para pengusaha IKM.

Pada kegiatan ini tim juga memberikan pelatihan untuk membuat akun media social seperti facebook dengan mempraktekkan langkah-langkah untuk membuatnya dan juga membuat fanpage untuk usaha yang dimiliki oleh para pengusaha tersebut. Pada pelatihan ini sebagian peserta dapat mengikuti petunjuk yang diberikan oleh tim untuk membuat fanpage tersebut. Namun ada juga peserta belum dapat mengikutinya karena keterbatasan pemahaman dan gadget yang dimiliki.

Dari pelaksanaan kegiatan pelatihan tersebut tim dapat melihat bahwa pelatihan ini adalah merupakan langkah awal sebagai pengenalan tentang pemanfaatan pemanfaatan media sosial sebagai media promosi. Untuk selanjutnya, tim juga memberikan kesempatan kepada peserta pelatihan yang ingin berkonsultasi tentang pengelolaan media sosial sebagai media pemasaran usaha agrowisata mereka. Tim pelatihan telah meninggalkan nomor kontak yang bisa dihubungi bila di waktu yang akan datang mereka membutuhkan bantuan dan ingin bertanya seputar pelaksanaan kegiatan promosi dan pemasaran agrowisata yang mereka bina dengan menggunakan media sosial. 


\section{Daftar Pustaka}

Anggoro, et. al. 2009. Direct Marketing dan Online Marketing. Jakarta: Universitas Sahid.

Ardianto, Elvinaro. 2010. Metode Penelitian untuk Public Realtions Kuantitatif dan Kualitatif. Bandung: Simbiosa Rekatama Media.

Effendi, Rahmat, I. Made Narka Tenaya \& I Made Sudarma. 2015. Pengembangan Agrowisata Pesuteraan Alam Sutera Sari Segara di Desa Sibangkaja Kecamatan Abiansemal. Jurnal Manajemen Agribisnis. Vol. 2 No. 3 Hal 147 - 154

Kotler, Philip. 2004. Manajemen Pemasaran. Jilid 1 dan Hilid 2 Edisi Milienium. Jakarta : Prenhallindo. Siladana, I Made, 2009, "Strategi Pembangunan Agrowisata Desa Candikuning Selatan Kabupaten Tabanan", Tesis. Program Pascasarjana Universitas Udayana.

Stelzner, A. Micheal. 2013. 2013 Social media marketing Industry Report: How Marketeers Are Using Social Media to Grow Their Bussinesses. Social Media Examiner.

Rizal, Veby Zilfania dan Evawani Elysa Lubis, Social Media Marketing Twitter dan Brand Image Restorant Burger, Jurnal Ilmu Komunikasi, Volume 5, Nomor 1, Maret 2014

Badan Pusat Statistik Kabupaten Siak, Kabupaten Siak dalam Angka 2019 